Revista de

Contabilidade e

Organizações

www.rco.usp.br
http://dx.doi.org/10.11606\%2Frco.v7i17.59279
Journal of

Accounting and

Organizations

www.rco.usp.br

\title{
Environmental, social + sustainability accounting: Quo Vadis?
}

\author{
Rob Gray ${ }^{\mathrm{a}}$ \\ Professor of Social and Environmental Accounting, School of Management - University of St Andrews ${ }^{a}$
}

\section{Article Info}

Article history:

Received: 15 March 2013

Accepted: 7 April 2013

Key words:

Sustainability Accounting

Environmental accounting

Environmental management systems

CSR

\begin{abstract}
Writing about trends is a dangerous task: much like forecasting it seems highly likely that whatever one identifies as key trends will have disappeared like mist on a summer morning within a few years. Only in retrospect will the principal current trends be visible. Nevertheless there is probably value in trying to categorise, synthesise and characterise one's field of endeavour if only to encourage some critical reflection on our mission as scholars.
\end{abstract}

Copyright (c) 2013 FEA-RP/USP. All rights reserved.

\section{ESSAY ON ENVIRONMENTAL ACCOUNTING.}

Environmental accounting now has a relatively long history Parker, 1971; Ullmann, 1976; Dierkes and Preston, 1977) and one which is so closely wrapped up the broader issues of both social responsibility/reporting and accounting for sustainability ${ }^{1}$. In many regards the lack of a formal (regulated) definition of environmental (and social and sustainability) accounting has been both a boon and a curse. On the one hand the lack of definition means that we inevitably struggle to say what environmental accounting actually is whilst simultaneously trying to engage with a considerable diversity of practice. On the other hand, this very looseness provides a freedom of expression and experimentation that is perhaps the singular strength of the field. One effect of this unregulated freedom seems to be that we as scholars are free (indeed duty bound) to explore how the wider demands of nature, society and sustainability potentially conflict with conventional accounting, economics and international financial capitalism.

1. Whilst I have been asked to make a few notes on environmental accounting, I think it is both impossible and incorrect to explicitly separate social, environ-

mental and sustainability issues in this context.

Corresponding author: Tel 551636023920

rhg1@st-andrews.ac.uk

St Andrews, Fife, KY16 9RJ

Scotland, UK
In these circumstances it is perhaps not a surprise to find 'environmental' matters recognised in financial accounting (e.g. through liabilities and risk); management accounting (e.g. through environmental management systems, win-win situations and capital investment methods); finance (in, for example, socially responsible investment) and audit (risk assessment and new forms of assurance, for example) as well as in the wider scope of reporting and (as we shall see) newer emergent fields.

As a recognised field of academic endeavour, environmental accounting probably emerged somewhere around 1990 and has grown exponentially ever since. In 1995, I wrote (Gray, 1995) that the purposes of (social and) environmental accounting were:

- the examination of the [social and environmental] effects of current accounting practice and how they arise;

- the investigation of how some of the adverse effects of current practice might be ameliorated; and

- the study of other possible ways of providing accounts of organisational activity.

This was intended as an agenda for engagement with accounting and as a basis for the obvious need for change in accounting, accountability and organisational activity. It is sobering to note that if one were to categorise academic research of the last 25 years I suspect that a relatively small amount of it would fall into any of these 
three categories.

The vast majority of research simply follows practice and seeks to record, codify and (to an extent) explain current practice. This is very depressing to one who saw environmental (and social and sustainability) accounting as a liberating, novel and potentially emancipatory activity. So the first trend that I see in environmental accounting is one I would never have anticipated and that is that the agenda is set by practice. Academics seem to be largely content to allow practice and policy to set their scholarly agendas. Environmental accounting is starting to look a little like normal science.

This might not matter - it might even be a sign of maturity in the area were it not for a number of key issues which sit at the heart of environmental (and social) accounting. As academics in environmental accounting we can choose and ascribe purpose to our scholarly and pedagogic activities. The purpose of most environmental accounting in practice - especially that within commercial enterprises and within financial markets - is to advance the cause of the organisation and its wealth-seeking investors. This is a purpose which sits perfectly well within the conventions of accounting and the accounting profession. However, the very purposes of environmental accounting suggested above recognise two critical issues, namely that: (a) that there can often be major conflicts between what is good for profit and dividends and what is good for nature and (vulnerable) societies; and (b) that the 'environment' as recognised in mainstream financial and management accounting is actually not about the environment at all - it is about risks and liabilities and threats that manifest in laws, costs and peoples' behaviours and, as such are only very distantly driven by the concerns of nature.

I see here a second trend: namely that researchers and teachers in environmental accounting are not embracing the literature and debate around nature, justice and the central role of modernity, international financial capitalism and the size and influence of multi-national corporations. In broad terms it is as if environmental accounting academics know a fair amount about accounting and organisations but relatively little about nature and justice. Of course there is a lot of good work that can be undertaken using a managerial lens but scholars need to critically assess whether their assumptions are justified through convention and profit seeking or through the needs of nature and justice.

Little illustrates this better than the use of the terms "sustainability" in environmental accounting. With very few exceptions (see, for example, Laine, 2010; Dumay et al, 2010) scholars are using the word "sustainability" to mean something: (probably environmental management systems + CSR, I think). What they are not doing is using the word "sustainability" to mean what Brundtland meant by the term - the capacity of human and non-human creatures to continue on the planet (a matter very seriously in doubt of course).

So my third trend is the increasing adoption of sloppy definitions, the failure to analyse taken-for-granted assumptions and an ignorance about the issues that are purportedly central to environmental accounting. The lack of serious analysis of either GRI (but see Moneva et al, 2006) or the so-called "integrated reporting" are cases in point here. Equally, the lazy assumption that sustainable development and CSR are equivalent reflects this problem. For me, social and environmental accounting has always been primarily about accountability and the considerable potential that this has for our futures. Very little practice is designed to discharge accountability and as long as researchers fail to examine and analyse their work more carefully, this profoundly radical notion remains inactive, (Owen, 2008).

These first three all seem like negative trends but I can also see some encouraging and positive trends. My fourth trend is probably the most obvious new trend in the literature and that is the emergence of a focus upon specific elements of the social and environmental agenda. There is a real upsurge in research around such issues as: carbon, water, human rights, bio-diversity and the supply chain. This focus on a more specific element of the social or environmental agenda has both positive and negative components to it, it seems to me. On the one hand such a focus actually starts to counter the earlier concern I expressed about researchers not understanding their field to work in human rights you need to know something about human rights and, preferably, something about moral philosophy; to work in water you need to know a lot about water and the biology, law and physics that are tied up in it. This is genuinely stimulating and encouraging. The downside, however, is arguably that this narrower focus is again both largely driven by emergent practice and largely avoids seeing the big pictures of systemic abuse, global devastation un-sustainability and the scary problems of population and consumption. How will this rend play out? Your guess is as good as mine.

My fifth trend is the most exciting trend I think. This is the steadily growing emergence of civil society accounts, counter-accounts and celebration of the multiple. I associate this trend with a wide range of scholars including Judy Brown, Christine Cooper, Colin Dey, Jesse Dillard and Ian Thomson who are picking up the opportunities offered by diversity, by silent and shadow accounts and re-empowering the external social audits. The CSEAR website illustrates the tip of this potential iceberg'.

Finally I would like to suggest two areas which whilst they are not yet major trends strike me as exceptionally important for the future. First, I would like to see a sixth trend in the expansion of research into non-profit entities and their accountability as well as their engagement with accounts of nature and justice. There is a strong emerging literature here and the pioneers in the area have been calling for this kind of work for some time now, (see, for example, Ball and Osborne, 2011). However a recent experience in writing about the area led me to the realisation that we have barely touched the surface of this field - charities, social enterprises, the World Bank, universities, United Nations - the list is endless. There is crucial important work to be done here.

Finally, I would hope that there might be a seventh trend that would see the social and environmental accounting community starting to embrace theorising rather more carefully. I do not mean the callow shopping for theories that so often happens - at the moment the easy option for researchers seems to be to adopt (some variant of) institutional theory without any thought or understanding. Maybe this is simply another manifestation of the second and third trends above but the issues are so very important that it behoves each of us to read widely,

2. http://www.st-andrews.ac.uk/csear/sa-exemplars/externalsocial-audits/ 
think carefully and then adopt the most nuanced understanding of our mission of which we are able.

As I said at the start, I have no idea if these trends are substantial, misleading or wishful thinking. They are the key trends I have in mind currently having been working with David Owen and Carol Adams to completely revise our text and in doing so to reflect upon the state of our field.

This has led us to question: the depth of our understandings (Chapters 2 and 3); how we theorise and inform our work (Chapter 4); the emerging trends in practice and normal science (Chapters 5-8) as well as the issues of definition (Chapter 9); the external social audits (Chapter 10); governance (Chapter 11); and the non-profit sector (Chapter 12). I admit to being guilty of blatant self-advertising here but should you want to know how and why we have developed any of these ideas, the text is the place for $y^{3} u^{3}$.

\section{REFERENCES}

Ball A. and S. P. Osborne (2011) Social accounting and public management: Accountability and the common good (Abingdon: Routledge

Dierkes M. \& L.E.Preston (1977) "Corporate Social Accounting and Reporting for the Physical Environment: A critical review and implementation proposal" Accounting, Organizations and Society 2(1) (pp3-22) reprinted in Gray R.H., K. J. Bebbington and S. Gray (eds) Socil and Environmental Accounting (Volume 1 in the Sage Library Series) (London: Sage) pp117-144

Dumay J., J. Guthrie and F. Farneti (2010) "GRI sustainability reporting guidelines for public and third sector organisations" Public Management Review 12(4) pp 531-548

Gray Rob (1995) Social and Environmental Accounting Research Briefing Paper Series (Wye: ESRC/GEC)

Laine M (2010) "Towards sustaining the status quo: Business talk of sustainability in Finnish corporate disclosures 1987-2005" European Accounting Review 19(2) pp247-274

Moneva, J. M., P. Archel and C. Correa (2006) "GRI and the camouflaging of corporate unsustainability" Accounting Forum 30(2) June (pp121-137)

Owen D. (2008) "Chronicles of wasted time? A personal reflection on the current state of , and future prospects for, social and environmental accounting research" Accounting, Auditing and Accountability Journal 21(2) pp240-267

Parker J. E. (1972) "Accounting and Ecology: A perspective" The Journal of Accountancy 134(4) pp41-46

3. The book is Rob Gray, David Owen and Carol Adams, (forthcoming) Accountability, Social Responsibility and Sustainability: Accounting for Society and the Environment (London: Pearson) reprinted in Gray R.H., K. J. Bebbington and S. Gray (eds) Social and Environmental Accounting (Volume 1 in the Sage Library Series) (London: Sage) pp145-154

Ullmann A.E. (1976) "The corporate environmental accounting system: a management tool for fighting environmental degradation" Accounting, Organizations and Society 1(1) (pp71-79) 